\title{
AMCoR
}

Asahikawa Medical University Repository http://amcor.asahikawa-med.ac.jp/

Brain Research (2010) 1344:25-33.

Meloxicam protects cell damage from 1-methyl-4-phenyl pyridinium toxicity via the phosphatidylinositol 3-kinase/Akt pathway in human dopaminergic neuroblastoma SH-SY5Y cells

Tasaki, Yoshikazu ; Omura, Tomohiro ; Yamada, Takehiro ; Ohkubo, Tomoko ; Suno, Manabu ; Iida, Shinya ; Sakaguchi, Tomoki ; Asari, Masaru ; Shimizu, Keiko ; Matsubara, Kazuo 


\section{Meloxicam protects cell damage from 1-methyl-4-phenyl pyridinium toxicity via the phosphatidylinositol 3-kinase/Akt pathway in human dopaminergic neuroblastoma SH-SY5Y cells}

Yoshikazu Tasaki ${ }^{a}$, Tomohiro Omura ${ }^{a}, b$, Takehiro Yamada ${ }^{a}$, Tomoko Ohkubo ${ }^{a}$, Manabu Suno ${ }^{a}$, Shinya Iida ${ }^{a}$, Tomoki Sakaguchi ${ }^{a}$, Masaru Asari $^{b}$, Keiko Shimizu ${ }^{b}$ and Kazuo Matsubara ${ }^{a}$ *

${ }^{\mathrm{a}}$ Department of Hospital Pharmacy \& Pharmacology, Asahikawa Medical College, Asahikawa 078-8510, Japan

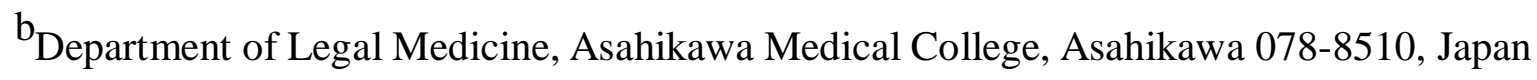

Total 22 pages including 8 figures and 1 supplementary figure.

*Corresponding Author. Department of Hospital Pharmacy \& Pharmacology, Asahikawa Medical College, Asahikawa 078-8510, Japan. Fax: +81-166-65-1392.

E-mail address: kmatsuba@asahikawa-med.ac.jp (K. Matsubara). 


\begin{abstract}
Parkinson's disease (PD) is a common neurodegenerative disorder characterized by dopaminergic neuronal death in the substantia nigra pars compacta. There is growing interest in the effects of nonsteroidal antiinflammatory drugs (NSAIDs) against PD progression. In this study, we investigated the neuroprotective effect of NSAIDs on neuronal damage induced by 1-methyl-4-phenyl pyridinium $\left(\mathrm{MPP}^{+}\right)$in human dopaminergic SH-SY5Y neuroblastoma cells. Of the NSAIDs tested, only meloxicam indicated protective effect on $\mathrm{MPP}^{+}$-induced neurotoxicity in SH-SY5Y cells, although such an effect was not established with indomethacin, ibuprofen and cyclooxygenase (COX)-2 selective inhibitors (NS-398 and CAY-10404). The neuroprotective effect of meloxicam against $\mathrm{MPP}^{+}$toxicity was specific, as toxicities induced by other cytotoxic agents (such as rotenone, MG-132, tunicamycin and ethacrynic acid) were not attenuated by meloxicam. The neuroprotective effect of meloxicam on $\mathrm{MPP}^{+}$-induced apoptosis was abolished by a phosphatidylinositol 3-kinase (PI3K) inhibitor, LY294002, but not by a MEK inhibitor, PD98059. The Akt phosphorylation levels were predominantly suppressed $4 \mathrm{~h}$ after $\mathrm{MPP}^{+}$incubation (i.e. when the cell toxicity was not apparently observed yet). Meloxicam completely prevented the Akt phosporylation suppression caused by $\mathrm{MPP}^{+}$exposure, while meloxicam per se did not promote the Akt phosphorylation. These results strongly suggest that the neuroprotective effect of meloxicam is mediated by the maintenance of cell survival signaling in the PI3K/Akt pathway, but not by COX-2 inhibition. Therefore, meloxicam may have therapeutic potential in preventing development or delaying progress of PD.
\end{abstract}


Classification terms

Section: 1. Cellular and Molecular Biology of Nervous Systems

Keywords:

Meloxicam

NSAIDs

Neuroprotection

Parkinson's disease

Akt

$\mathrm{MPP}^{+}$

Abbreviations: PD, Parkinson's disease; $\mathrm{MPP}^{+}$, 1-methyl-4-phenyl pyridinium; PI3K, phosphatidylinositol 3-kinase; MPTP, 1-methyl-4-phenyl-1,2,3,6-tetrahydropyridine; COX, cyclooxygenase; NSAIDs, nonsteroidal antiinflammatory drugs; MEK, MAP-ERK kinase; MAP, mitogen activated protein; ERK, extracellular signal-regulated kinase; LDH, lactate dehydrogenase; JNK, c-Jun N-terminal kinase; PI, propidium iodide 


\section{Introduction}

Parkinson's disease (PD) is the second most prevalent neurodegenerative disease, which elicits motor disturbances such as tremors, rigidity, bradykinesia and akinesia (Sian et al., 1999). Pathological features of PD are characterized by intracellular inclusions, Lewy bodies, and a marked loss of nigrostriatal dopaminergic neurons in the brain (Ehringer and Hornykiewicz, 1960). Currently, there are several effective medications to treat the symptoms by compensation of decreased dopamine, such as the use of levodopa and dopamine agonists. However, these medications neither protect progressive dopaminergic cell loss per se in PD progression nor improve the problems of dyskinesia and their fluctuating efficacies after long-term use (Marek et al., 2002; Fahn and the Parkinson Study Group, 2005). Therefore, novel and potential drugs are still needed to protect or ameliorate progressive dopaminergic neuronal degeneration (Koller and Tse, 2004).

In the etiology of idiopathic PD, the mechanism of neuronal death is not fully understood. It has been reported that inflammation is up-regulated in brains of PD patients (McGeer et al., 1988; Whitton, 2007), and parallel changes in microglial activation and corresponding dopaminergic terminal loss are observed in the affected nigrostriatal pathway of early PD (Ouchi et al., 2005). Despite some controversial findings, the beneficial effects of non-aspirin and nonsteroidal antiinflammatory drugs (NSAIDs) on PD progression have been supported by several epidemiological studies (Chen et al., 2003; Hernan et al., 2006; Ton et al., 2006), suggesting that antiinflammatory agents may prevent neuronal death in PD. In an experimental PD model, NSAIDs, aspirin, meloxicam, indomethacin and rofecoxib, have displayed neuroprotective effects in vivo (Kurkowska-Jastrzebska et al., 2002; Teismann and Ferger, 2001; Teismann et al., 2003). The neuronal protective effect of NSAIDs has been supposedly achieved through the 
inhibition of cyclooxygenase $(\mathrm{COX})-2$ that subsequently reduce toxic mediators (such as inflammatory cytokines and oxidants) derived from activated microglia, which have been observed in the affected substantia nigra pars compacta of PD patients (McGeer et al., 1988; Ouchi et al., 2005). However, up-regulation of COX-2 has been found not only in microglia but also in neurons of substantia nigra pars compacta of PD patients and mice intoxicated by 1-methyl-4-phenyl-1,2,3,6-tetrahydropyridine (MPTP) (Liberatore et al., 1999; Teismann et al., 2003). The role of neuronal COX-2 in neuronal death related to PD pathogenesis remains unknown.

The present study investigated whether NSAIDs directly rescued neuronal death via COX-2 inhibition in a neural cell line. The protective effect of NSAIDs on neuronal death induced by 1-methyl-4-phenyl pyridinium $\left(\mathrm{MPP}^{+}\right)$, a toxic metabolite of MPTP (Chiba et al., 1984; Cleeter et al., 1992), was studied using human dopaminergic SH-SY5Y neuroblastoma cells which express COX-2 (Alique et al., 2007). Furthermore, we identified the signal pathway related with the neuroprotective effect exhibited by a certain NSAID (meloxicam), and proposed possible therapeutic application of meloxicam in PD treatment.

\section{Results}

\subsection{Effects of NSAIDs on cell toxicity induced by $\mathrm{MPP}^{+}$exposure}

Treatment with $\mathrm{MPP}^{+}$showed a marked decrease in cell viability and an increase in lactate dehydrogenase (LDH) leakage in SH-SY5Y cells (Fig. 1). Morphologically, surviving cells lost almost all neurites after $\mathrm{MPP}^{+}$treatment for $24 \mathrm{~h}$ (Fig. 2A). In this study, we tested the effects of five NSAIDs on $\mathrm{MPP}^{+}$-induced neurotoxicity: viz., indomethacin, 
meloxicam, CAY-10404, NS-398 and ibuprofen. Of these chemicals, meloxicam dose-dependently improved cell viability and LDH leakage induced by $\mathrm{MPP}^{+}$exposure (Fig. 1). We further confirmed this neuroprotective effect of meloxicam with the propidium iodide (PI)-stained assay by which dead cells were identified and counted directly using a fluorescence microscope (Fig. 2B). In addition, meloxicam completely prevented morphological changes in surviving cells after $\mathrm{MPP}^{+}$exposure (Fig. 2A). Indomethacin and NS-398 showed limited effectiveness against cell viability, yielding a weak - moderate beneficial effect (only when the effect was assessed by the cell viability both in the presence and absence of $\mathrm{MPP}^{+}$; Fig. 1A). The other chemicals, CAY-10404 and ibuprofen, did not attenuate the $\mathrm{MPP}^{+}$toxicity.

\subsection{Effect of meloxicam on cell toxicity of rotenone, MG-132, tunicamycin or ethacrynic acid}

To characterize the neuroprotective effects of meloxicam, we evaluated the effects of meloxicam on toxicities induced by 4 different types of cytotoxic agents (rotenone: a mitochondrial complex I inhibitor; MG-132: a proteasome inhibitor; tunicamycin: an endoplasmic reticulum stress inducer; and ethacrynic acid: a reducing agent of cellular glutathione). Meloxicam elicited significant $(p<0.001)$ protective effects on cells exposed to $\mathrm{MPP}^{+}$(3 mM) for $48 \mathrm{~h}$ (Fig. 3). However, no favorable effect of meloxicam on cell viability was observed when cells were incubated with rotenone, MG-132, tunicamycin or ethacrynic acid (Fig. 3A). When cell toxicity was based on LDH leakage, meloxicam prevented cell toxicity induced by $10 \mu \mathrm{M}$ ethacrynic acid $(p<0.05)$ without affecting LDH leakage induced by rotenone, MG-132 or tunicamycin (Fig. 3B). 


\subsection{Involvement of anti-apoptotic intracellular signaling pathway}

The involvement of major anti-apoptotic intracellular signaling pathways (such as the MEK/ERK and PI3K/Akt) in the mechanism of meloxicam effect was investigated. Either PD985059 (MEK inhibitor) or LY294002 (PI3K inhibitor) was incubated with $\mathrm{MPP}^{+}$(5 $\mathrm{mM})$ and meloxicam $(10 \mu \mathrm{M})$ for $24 \mathrm{~h}$ before cell toxicity was evaluated based on cell viability and LDH assays. Results with PD98059 (1 and $10 \mu \mathrm{M})$ and LY294002 (1 and 10 $\mu \mathrm{M}$ ) did not indicate any improvement on $\mathrm{MPP}^{+}$-induced cell damage (Fig. 4). Notice that the preventive effect of meloxicam on $\mathrm{MPP}^{+}$toxicity was significantly $(p<0.001)$ diminished by the co-incubation with $10 \mu \mathrm{M}$ LY294002 (Figs. 4B \& 4D), although this was not the case with PD98059 (Figs. 4A \& 4C). The co-incubation with $30 \mu \mathrm{M}$ wortmannin, which is a non-specific PI3K inhibitor, also reduced the neuroprotective effect of meloxicam $(10 \mu \mathrm{M})$ against $\mathrm{MPP}^{+}$toxicity (data not shown).

\subsection{Meloxicam prevented apoptosis induced by $\mathrm{MPP}^{+}$}

$\mathrm{MPP}^{+}$is known to cause apoptosis and DNA fragmentation in SH-SY5Y cells. It would be of interest to elucidate if meloxicam prevented $\mathrm{MPP}^{+}$-induced apoptosis. As such, we observed the smear DNA fragmentation using agarose gel electrophoresis after having cells incubated with $5 \mathrm{mM} \mathrm{MPP}{ }^{+}$for $24 \mathrm{~h}$ (Fig. 5A). The results of co-incubation with meloxicam $(30 \mu \mathrm{M})$ clearly indicated that meloxicam prevented $\mathrm{MPP}^{+}$-induced DNA fragmentation, while concomitant treatment with LY294002 $(10 \mu \mathrm{M})$ abolished the protective effect of meloxicam (Fig. 5A).

To further investigate whether meloxicam exerted the anti-apoptotic effect, cleavage of caspase- 3 was detected after having cells incubated with $5 \mathrm{mM} \mathrm{MPP}^{+}$for $18 \mathrm{~h}$ by Western 
blot analysis. As shown in Fig. 5B, meloxicam $(30 \mu \mathrm{M})$ inhibited cleavage of caspase-3 induced by $\mathrm{MPP}^{+}$, and LY294002 $(10 \mu \mathrm{M})$ reduced the protective effect of meloxicam. Furthermore, morphological changes of cells treated with $\mathrm{MPP}^{+}$were blocked by the co-incubation with meloxicam $(30 \mu \mathrm{M})$, and this cell-salvaging effect of meloxicam was diminished by LY294002 (10 $\mu \mathrm{M})$ (Fig. 2A).

\subsection{Effect of meloxicam on phosphorylation of Akt, ERK, JNK and p38}

To confirm the involvement of PI3K/Akt pathway in the mechanism of meloxicam action, phosphorylation of Akt at serine 473 was measured after incubation with $\mathrm{MPP}^{+}$using Western blot analysis. Although cell toxicity assesed by either cell viablitiy or LDH leakage was not apparently observed after 4-h incubation (data not shown), MPP significantly reduced Akt phosphorylation and meloxicam completely reversed this $\mathrm{MPP}^{+}$-induced reduction after 4-h incubation (Fig. 6A). A significant up-regulating effect of meloxicam on phosphorylated Akt was observed even after 18-h incubation (Fig. 6B). Despite inhibitory and reversal effects on Akt phosphorylation were respectively observed with $\mathrm{MPP}^{+}$and meloxicam, the total Akt levels did not change in any of the experimental groups (Figs. 6C \& 6D). However, meloxicam itself $(10$ or $30 \mu \mathrm{M})$ did not affect

phosphorylation of Akt after 4- and 18-h incubation without $\mathrm{MPP}^{+}$(data not shown). On the other hand, when phosphorylation levels of ERK, JNK and p38 were analyzed after 4-h incubation with/without meloxicam $(30 \mu \mathrm{M})$ in the presence of $\mathrm{MPP}^{+}(5 \mathrm{mM})$, no statistical significant difference in the phosphorylation level was observed (Fig. 7).

\section{Discussion}


In this study, we demonstrated that meloxicam protected neuronal damage from $\mathrm{MPP}^{+}$ toxicity in SH-SY5Y cells, although the other NSAIDs tested did not prevent $\mathrm{MPP}^{+}$-induced neuronal death. When assessed by the cell viability test, indomethacin and NS-398 slightly attenuated $\mathrm{MPP}^{+}$-induced toxicity. However, both drugs slightly promoted cell growth in cultured media without $\mathrm{MPP}^{+}$through an unknown mechanism, and did not show any significant protective effect as evaluated by the LDH leakage test. Thus, these drugs would not indicate neuroprotective activity against $\mathrm{MPP}^{+}$cytotoxicity. NS-398 and CAY-10404 are more potent and selective COX-2 inhibitors than meloxicam (Habeeb et al., 2000; Warner et al., 1999). COX-2 protein has been previously shown to be expressed in SH-SY5Y cells (Alique et al., 2007), and this was confirmed in this study (data not shown). These results imply that the neural protective effect of meloxicam could be mediated by a mechanism different from COX-2 inhibition. Additionally, MPP ${ }^{+}$ toxicity has been shown to develop independently from COX activity in rat mesencephalic primary cultured cells (Carrasco et al., 2005).

The second interesting finding of this study indicated that meloxicam showed a specific neuroprotective effect against $\mathrm{MPP}^{+}$-induced toxicity without affecting toxicities induced by other types of cytotoxic agents (such as rotenone, MG-132, tunicamycin and ethacrynic acid). This result strongly suggests that meloxicam exerts the neuroprotective effect by acting on a molecule related to the intracellular signaling cascade involved in the onset of $\mathrm{MPP}^{+}$toxicity. Rotenone and $\mathrm{MPP}^{+}$have a toxicological mechanism similar to that of mitochondrial complex I inhibitors, which cause mitochondrial dysfunction to eventually inflict cell death. However, our results suggest that the mechanism of MPP ${ }^{+}$to induce mitochondrial dysfunction should be different from that of rotenone. Therefore, the site of action involved in the neuronal protection of meloxicam is most likely to be at the upstream signaling cascade prior to the mitochondria in the $\mathrm{MPP}^{+}$-induced neuronal 
death. The recently established two pro-apoptotic molecules, p38 MAP kinase and c-Jun N-terminal kinase (JNK), are rapidly activated (Cassarino et al., 2000) before the mitochondrial collapse (Fall and Bennett, 1999) when SH-SY5Y cells are exposed to MPP ${ }^{+}$ A JNK activation inhibitor, CEP-1347, suppresses MPTP-induced nigral dopaminergic cell death in vivo (Saporito et al., 1999). Rotenone-induced neuronal death in SH-SY5Y cells is also attenuated by genetic suppression of JNK or p38 pathway (Newhouse et al., 2004). Therefore, meloxicam is unlikely to behave as a JNK or a p38 MAP kinase inhibitor when exerting its neuroprotective effect. This was supported by the present results, although our results can not exclude involvement of $\mathrm{JNK}_{\text {in }} \mathrm{MPP}^{+}$-induced toxicity. On the other hand, the activation of pro-survival signaling cascades, MEK/ERK and PI3K/Akt, has been shown to rescue cells from $\mathrm{MPP}^{+}$toxicity (Halvorsen et al., 2002; Heumann et al., 2000; Shimoke and Chiba, 2001). Taken together, it may be beneficial to investigate whether the two pro-survival cascades would account for the neuroprotection of meloxicam.

The third notable finding of this study showed that the neuroprotective effect of meloxicam was mediated via the PI3K/Akt signaling pathway. We identified that a PI3K inhibitor, LY294002, abolished the neuroprotective effects of meloxicam against $\mathrm{MPP}^{+}$in three independent assays: viz., cell toxicity, DNA fragmentation and Western blot assays; however, this was not the case for an MEK inhibitor, PD98059. Worthy of mention is the significantly reduced level of Akt phosphorylation observed $4 \mathrm{~h}$ after the incubation with $\mathrm{MPP}^{+}$despite cell toxicity was not being apparent then. Meloxicam completely prevented this reduction of Akt phosphorylation induced by $\mathrm{MPP}^{+}$exposure. This protective effect of meloxicam was considered to be brought by the direct inhibition of $\mathrm{MPP}^{+}$-induced down-regulation of Akt phosphorylation, since meloxicam itself did not increase its phosphorylation.

From the above findings, we formulated the following hypothesis (Fig. 8): 1) $\mathrm{MPP}^{+}$ 
inhibited Akt phosphorylation, and then activated Bad and/or, possibly, JNK to promote cell death; 2) Meloxicam prevented the reduction of Akt phosphorylation induced by $\mathrm{MPP}^{+}$and normalized the PI3K/Akt signaling to suppress Bad and/or JNK, resulting in promoting cell survival. Activation of JNK promotes Bax translocation to mitochondria through phosphorylation of 14-3-3, a cytoplasmic anchor of Bax, resulting in the release of cytochrome c and apoptosis (Tsuruta et al., 2004). However, a major factor contributing to the survival of central neurons could be the stimulatory effects of the PI3K/Akt pathway. Akt is a critical factor for cell survival by the phosphorylation of a number of pro-survival and pro-apoptotic substrates. Akt notably phosphorylates and inactivates the Bcl-2 family BAD protein, which inhibits mitochondrial-dependent apoptosis (Tulasne and Foveau, 2008). In addition, PI3K inhibition leads to increased JNK phosphorylation and cell death (Tsuruta et al., 2004), although activation of JNK was not seen during $\mathrm{MPP}^{+}$exposure in this study. However, further studies are needed to reveal the exact protective mechanism of meloxicam against drug-induced cell death.

In conclusion, the present results indicate that the neuroprotective effect of meloxicam against $\mathrm{MPP}^{+}$toxicity may be mediated by maintaining cell survival signaling in the PI3K/Akt pathway, but not by COX-2 inhibition. However, our results can not in toto exclude the role of glial COX-2 in neuronal cell death in vivo. Interestingly, a recent study has shown that selective loss of dopamine neurons has been accompanied by a marked decrease of Akt and phosphorylated Akt in the substantia nigra pars compacta of PD patients, suggesting that defective Akt could be linked to loss of dopaminergic neurons in PD (Timmons et al., 2009). Thus, our results may provide a novel additional strategy for the treatment of PD patients. Meloxicam may harbor therapeutic potential in preventing development or delaying progress of the disease. 


\section{Experimental procedures}

\subsection{Materials}

All antibodies were purchased from Cell Signaling Technology (Danvers, MA, USA). CAY10404, MG-132 and wortmannin were obtained from Cayman Chemical (Ann Arbor, MI, USA) and Calbiochem (San Diego, CA, USA), respectively. $\mathrm{MPP}^{+}$iodide, indomethacin, meloxicam sodium hydrate, tunicamycin, PD98059, and LY294002 were from Sigma (St Louis, MO, USA). All other chemicals (Wako, Osaka, Japan) used in the experiments were either of the highest or analytical grade.

\section{2. $\quad$ Cell culture and drug treatment}

SH-SY5Y human neuroblastoma cells were maintained in Dulbecco's modified Eagle's medium (DMEM) containing heat-inactivated fetal bovine serum (FBS, 10\%), penicillin (100 U/ml) and streptomycin $(100 \mu \mathrm{g} / \mathrm{ml})$ before being seeded onto a 6- or 96-well plate or a chamber slide at $1.5 \times 10^{5}$ cells $/ \mathrm{cm}^{2}$ and cultured in a humidified incubator $(95 \%$ air and $5 \% \mathrm{CO}_{2}$ ) for $24 \mathrm{~h}$ at $37^{\circ} \mathrm{C}$. After rinsing, cells in the plates were treated with a test-agent (dissolved in $0.1 \%$ ethanol or dimethyl sulfoxide) for $4-48 \mathrm{~h}$ in the serum-free culture medium containing antibiotics.

\subsection{Evaluation of cell toxicity}

Cell viability was assessed by measuring optical density at $450 \mathrm{~nm}$ with a microplate reader (ImmunoMini NJ-2300, System Instruments, Tokyo, Japan) after 2.5-h loading with 
WST-8 test reagent (Dojindo, Kumamoto, Japan). Cell damage was determined by the LDH leakage into the culture medium from cells using the LDH-cytotoxic test (Wako, Osaka, Japan). LDH leakage was determined by measuring the optical density at $540 \mathrm{~nm}$. When cells were treated with culture medium containing $1 \%$ Tween 20, LDH leakage into the culture medium was designated as $100 \%$.

Cells were stained with PI and Hoechst 33342 after 24-h incubation with tested drugs. PI is membrane impermeant and generally excluded from viable cells, and is commonly used for identifying dead cells. Hoechst 33342 stains all cells. The final concentrations of PI and Hoechst 33342 were 25 and $250 \mu \mathrm{g} / \mathrm{ml}$, respectively. Stained cells in three random fields per each treatment were counted under a Leica (Wetzlar, Germany) AF-6000 fluorescence microscope system with the appropriate filters for PI and Hoechst 33342, and then the percentage of PI-positive cells was calculated.

\subsection{DNA fragmentation assay}

After 18-h exposure to each drug, treated cells were rinsed with phosphate-buffered saline (PBS, pH 7.4) and lysed with $100 \mu \mathrm{l}$ of lysis buffer containing $10 \mathrm{mM}$ Tris- $\mathrm{HCl}(\mathrm{pH} 7.4)$, $10 \mathrm{mM}$ EDTA and $0.5 \%$ TritonX-100 for $10 \mathrm{~min}$ at $4^{\circ} \mathrm{C}$. The cell lysate was centrifuged at $15,000 \mathrm{x} \mathrm{g}$ for $10 \mathrm{~min}$ at $4^{\circ} \mathrm{C}$, and the decanted supernatant was treated with RNase A solution $(2 \mu \mathrm{l}, 10 \mathrm{mg} / \mathrm{ml})$ and further incubation for $60 \mathrm{~min}$ at $37^{\circ} \mathrm{C}$. The mixture was thereafter treated with a $2-\mu 1$ aliquot of proteinase $\mathrm{K}$ solution (> 600 units $/ \mathrm{ml}$ ) before standing for $30 \mathrm{~min}$ at $50^{\circ} \mathrm{C}$. The mixture was further treated with concentrated $\mathrm{NaCl}(5$ M) and isopropanol (final concentrations: $0.5 \mathrm{M}, 50 \%$ respectively), and allowed to stand overnight at $-20^{\circ} \mathrm{C}$. The mixture was then centrifuged at $15,000 \mathrm{x} \mathrm{g}$ for $20 \mathrm{~min}$ at $4^{\circ} \mathrm{C}$, and the supernatant was discarded. The pellet was suspended in $20 \mu 1$ of $10 \mathrm{mM}$ Tris buffer 
( $\mathrm{pH}$ 7.4) containing $1 \mathrm{mM}$ EDTA. After the DNA concentration was determined by monitoring absorbance at $260 \mathrm{~nm}$, the DNA sample $(20 \mu \mathrm{g})$ was mixed with bromphenol blue (final concentration: $0.04 \%$ ) and sucrose (final concentration: $6.7 \%$ ) and electrophoresed on $1.5 \%$ agarose gel with $90 \mathrm{mM}$ Tris-borate buffer ( $\mathrm{pH} 8.3$ ) containing 2 mM EDTA and $1 \mu \mathrm{g} / \mathrm{ml}$ ethidium bromide. DNA fragmentation was observed under ultraviolet light.

\subsection{Western blotting}

After rinsing with ice-cold PBS $(1 \mathrm{ml})$, cells were sonicated in $100 \mu \mathrm{l}$ of ice-cold lysis buffer containing $20 \mathrm{mM}$ Tris buffer ( $\mathrm{pH} 7.5$ ), $250 \mathrm{mM} \mathrm{NaCl}, 1 \%$ Triton X-100, 1mM EDTA, 1mM dithiothreitol, $10 \mathrm{mM} \mathrm{NaF}, 2 \mathrm{mM}$ sodium orthovanadate and the protease-inhibitor cocktail (EDTA-free complete type; Roche Applied Science, Switzerland). Cellular debris was removed from the lysate by centrifugation $(15,000 \mathrm{x} \mathrm{g})$, and the protein content of supernatant was determined using the BCA protein assay kit (Thermo Fisher Scientific, Rockford, IL, USA). After boiling with Laemmli buffer for 5 min, proteins $(20 \mu \mathrm{g})$ separated by $7.5 \%$ SDS-polyacrylamide gel electrophoresis were electrophoretically transferred onto a polyvinylidene fluoride membrane. The membrane was sequentially treated with Block Ace (DS Pharma Biomedical, Osaka, Japan) and incubated overnight at $4^{\circ} \mathrm{C}$ with anti-phosphorylated-Akt $(1: 1,000)$ or anti-Akt $(1: 5,000)$ from rabbit in $10 \mathrm{mM}$ Tris buffer $(\mathrm{pH} 7.5)$ containing $0.9 \% \mathrm{NaCl}, 0.05 \%$ Tween 20 and $10 \%$ methanol (TBST). For the other antibodies for phosphorylated- and total- MAP kinases and full and cleaved caspase-3, the dilution at 1:1,000 in TBST was used except for anti-phosphorylated ERK and $\beta$-actin $(1: 2,000)$. The membrane was washed three times with TBST and probed with horseradish peroxidase (HRP)-conjugated anti-rabbit IgG 
antibody from donkey (1 : 10,000, GE Healthcare, Little Chalfont, UK) for $1 \mathrm{~h}$ at room temperature. The washing procedure was repeated before the membrane was treated with a chemiluminescent reagent (ECLplus, GE Healthcare, Little Chalfont, UK). The proteins were visualized using an LAS3000 image analyzer (FUJIFILM, Tokyo, Japan).

\subsection{Statistical Analysis}

Data were analyzed by one factorial ANOVA followed by the Tukey's multiple comparison test for post-hoc significance testing. The Student's $t$-test was used for comparison between two groups at any one time. 


\section{References}

Alique, M., Herrero, J. F., Lucio-Cazana, F. J., 2007. All-trans retinoic acid induces COX-2 and prostaglandin E2 synthesis in SH-SY5Y human neuroblastoma cells: involvement of retinoic acid receptors and extracellular-regulated kinase 1/2. J. Neuroinflammation doi: 10.1186/1742-2094-4-1.

Carrasco, E., Casper, D., Werner, P., 2005. Dopaminergic neurotoxicity by 6-OHDA and $\mathrm{MPP}^{+}$: differential requirement for neuronal cyclooxygenase activity. J. Neurosci. Res. $81,121-131$.

Cassarino, D.S., Halvorsen, E.M., Swerdlow, R.H., Abramova, N.N., Parker Jr, W.D., Sturgill, T.W., Bennett Jr, J.P., 2000. Interaction among mitochondria, mitogen-activated protein kinases, and nuclear factor-kappaB in cellular models of Parkinson's disease. J. Neurochem. 74, 1384-1392.

Chen, H., Zhang, S. M., Hernan, M.A., Schwarzschild, M.A., Willett, W.C., Colditz, G.A., Speizer, F.E., Ascherio, A., 2003. Nonsteroidal anti-inflammatory drugs and the risk of Parkinson disease. Arch. Neurol. 60, 1059-1064.

Chiba, K., Trevor, A., Castagnoli Jr, N., 1984. Metabolism of the neurotoxic tertiary amine, MPTP, by brain monoamine oxidase. Biochem. Biophys. Res. Commun. 120, 574-578.

Cleeter, M.W., Cooper, J.M., Schapira, A.H., 1992. Irreversible inhibition of mitochondrial complex I by 1-methyl-4-phenylpyridinium: evidence for free radical involvement. $\mathrm{J}$. Neurochem. 58, 786-789.

Ehringer, H., Hornykiewicz, O., 1960. Distribution of noradrenaline and dopamine (3-hydroxytyramine) in the human brain and their behavior in diseases of the extrapyramidal system. Klin. Wochenschr. 38, 1236-1239.

Fall, C.P., Bennett Jr, J.P., 1999. Characterization and time course of MPP+ -induced apoptosis in human SH-SY5Y neuroblastoma cells. J. Neurosci. Res. 55, 620-628. 
Fahn, S., the Parkinson Study Group, 2005. Does levodopa slow or hasten the rate of progression of Parkinson's disease? J. Neurol. 252 suppl 4, IV37-IV42.

Habeeb, A.G., Praveen-Rao, P.N., Knaus, E.E., 2000. Design and syntheses of diarylisoxazoles: novel inhibitors of cyclooxygenase-2 (COX2) with analgesic-antiinflammatory activity. Drug Dev. Res. 51, 273-286.

Halvorsen, E.M., Dennis, J., Keeney, P., Sturgill, T.W., Tuttle, J.B., Bennett Jr, J.B. 2002. Methylpyridinium $\left(\mathrm{MPP}^{+}\right)$- and nerve growth factor-induced changes in pro- and anti-apoptotic signaling pathways in SH-SY5Y neuroblastoma cells. Brain Res. 952, 98-110.

Hernan, M.A., Logroscino, G., Garcia Rodriguez, L.A., 2006. Nonsteroidal anti-inflammatory drugs and the incidence of Parkinson disease. Neurology 66, 1097-1099.

Heumann, R., Goemans, C., Bartsch, D., Lingenhohl, K., Waldmeier, P.C., Hengerer, B., Allegrini, P.R., Schellander, K., Wagner, E.F., Arendt, T., Kamdem, R.H., Obst-Pernberg, K., Narz, F., Wahle, P., Berns, H., 2000. Transgenic activation of Ras in neurons promotes hypertrophy and protects from lesion-induced degeneration. J. Cell. Biol. 151, $1537-1548$.

Koller, W.C., Tse, W., 2004. Unmet medical needs in Parkinson's Disease. Neulorogy 62, S1-8.

Kurkowska-Jastrzebska, I., Babiuch, M., Joniec, I., Przybylkowski, A., Czlonkowski, A., Czlonkowska, A., 2002. Indomethacin protects against neurodegeneration caused by MPTP intoxication in mice. Int. Immunopharmacol. 2, 1213-1218.

Liberatore, G.T., Jackson-Lewis, V., Vukosavic, S., Mandir, A.S., Vila, M., McAuliffe, W.G.., Dawson, V.L., Dawson, T.M., Przedborski, S, 1999. Inducible nitric oxide synthase stimulates dopaminergic neurodegeneration in the MPTP model of Parkinson 
disease. Nat. Med. 5, 1403-1409.

Marek, K., Jennings, D., Seibyl, J., 2002. Do dopamine agonists or levodopa modify Parkinson's disease progression? Eur. J. Neurol. 9 (Suppl 3), 15-22.

McGeer, P.L., Itagaki, S., Boyes, B.E., McGeer, E.G., 1988. Reactive microglia are positive for HLA-DR in the substantia nigra of Parkinson's and Alzheimer's disease brains. Neurology 38, 1285-1291.

Newhouse, K., Hsuan, S.L., Chang, S.H., Cai, B., Wang, Y., Xia, Z., 2004. Rotenone-induced apoptosis is mediated by p38 and JNK MAP kinases in human dopaminergic SH-SY5Y cells. Toxicol. Sci. 79, 137-146.

Ouchi, Y., Yoshikawa, E., Sekine, Y., Futatsubashi, M., Kanno, T., Ogusu, T., Torizuka, T., 2005. Microglial activation and dopamine terminal loss in early Parkinson's disease. Ann. Neurol. 57, 168-175.

Riederer, P., Wuketich, S. 1976. Time course of nigrostriatal degeneration in Parkinson's disease: a detailed study of influential factors in human brain amine analysis. J. Neural. Transm. 38, 277-301.

Saporito, M.S., Brown, E.M., Miller, M.S., Carswell, S., 1999. CEP-1347/KT-7515, an inhibitor of c-jun N-terminal kinase activation, attenuates the 1-methyl-4-phenyl tetrahydropyridine-mediated loss of nigrostriatal dopaminergic neurons in vivo. J. Pharmacol. Exp. Ther. 288, 421-427.

Shimoke, K., Chiba, H., 2001. Nerve growth factor prevents 1-methyl-4-phenyl-1,2,3,6-tetrahydropyridine-induced cell death via the Akt pathway by suppressing caspase-3-like activity using PC12 cells: relevance to therapeutical application for Parkinson's disease. J. Neurosci. Res. 63, 402-409.

Sian, J., Gerlach, M., Youdim, M.B., Riederer, P., 1999. Parkinson's disease: a major hypokinetic basal ganglia disorder. J. Neural. Transm. 106, 443-476. 
Timmons, S., Coakley, M.F., Moloney, A.M., Neill, C.O., 2009. Akt signal transduction in Parkinson's disease. Neurosci. Lett. 467, 30-35.

Teismann, P., Ferger, B., 2001. Inhibition of the cyclooxygenase isoenzymes COX-1 and COX-2 provide neuroprotection in the MPTP-mouse model of Parkinson's disease. Synapse 39, 167-174.

Teismann, P., Tieu, K., Choi, D.K., Wu, D.C., Naini, A., Hunot, S., Vila, M., Jackson-Lewis, V., Przedborski, S., 2003. Cyclooxygenase-2 is instrumental in Parkinson's disease neurodegeneration. Proc. Natl. Acad. Sci. USA 100, 5473-5478.

Ton, T.G., Heckbert, S.R., Longstreth, W.T., Jr., Rossing, M.A., Kukull, W.A,, Franklin, G.M., Swanson, P.D., Smith-Weller, T., Checkoway, H. 2006. Nonsteroidal anti-inflammatory drugs and risk of Parkinson's disease. Mov. Disord, 21, 964-969.

Tsuruta, F., Sunayama, J., Mori, Y., Hattori, S., Shimizu, S., Tsujimoto, Y., Yoshioka, K., Masuyama, N., Gotoh, Y., 2004. JNK promotes Bax translocation to mitochondria through phosphorylation of 14-3-3 proteins. EMBO J. 23, 1889-1899.

Tulasne, D., Foveau, B., 2008. The shadow of death on the MET tyrosine kinase receptor. Cell Death Differ. 15, 427-434

Warner, T.D., Giuliano, F., Vojnovic, I., Bukasa, A., Mitchell, J.A., Vane, J.R., 1999. Nonsteroid drug selectivities for cyclo-oxygenase-1 rather than cyclo-oxygenase-2 are associated with human gastrointestinal toxicity: a full in vitro analysis. Proc. Natl. Acad. Sci. USA 96, 7563-7568.

Whitton, P.S., 2007. Inflammation as a causative factor in the aetiology of Parkinson's disease. Br. J. Pharmacol. 150, 936-976. 


\section{Figure Legends}

Fig. 1 - Effects of NSAIDs on cell toxicity induced by MPP ${ }^{+}$exposure. SH-SY5Y cells were incubated at indicated concentrations of the respective non-steroid anti-inflammatory drugs (NSAIDs) for $24 \mathrm{~h}$ in the presence (solid column) or absence (open column) of $5 \mathrm{mM}$ $\mathrm{MPP}^{+}$. Cell toxicity was evaluated by cell viability (A) and LDH assays (B). Data are expressed as the mean \pm SEM of at least three independent experiments. Differences where $p<0.05(*)$ and $<0.001(* *)$ were significant when compared with the corresponding vehicle group by the Tukey's test for one-factorial ANOVA.

Fig. 2 - Protective effect of meloxicam determined by the PI-stained assay. SH-SY5Y cells were incubated with the test-agents for $24 \mathrm{~h}: \mathrm{MPP}^{+}(5 \mathrm{mM})$, meloxicam $(30 \mu \mathrm{M})$ and LY294002 $(10 \mu \mathrm{M})$. (A) Representative micrographs were obtained after double staining with Hoechst 33342 and PI. The scale bar: $300 \mu \mathrm{m}$. (B) PI- and Hoechst 33342-stained cells were counted in three random fields per each treatment and then the percentage of PI-positive cells was calculated. Data are expressed as the mean \pm SEM of three independent experiments. Differences where $p<0.001(* *)$ were significant by the Tukey's test for one-factorial ANOVA.

Fig. 3 - Effect of meloxicam on cell toxicity of rotenone, MG-132, tunicamycin or ethacrynic acid. SH-SY5Y cells were incubated at indicated concentrations of cytotoxic agents for $48 \mathrm{~h}$ in the presence (solid column) or absence (open column) of $30 \mu \mathrm{M}$ meloxicam. The effect of meloxicam was determined by cell viability (A) and LDH (B) assays. Data are represented as the mean \pm SEM of $3-5$ independent experiments. Differences where $p<0.05(*)$ and $<0.001(* *)$ were significant when compared with the 
meloxicam-untreated group by the Student's $t$-test.

Fig. 4 - Effects of a MEK inhibitor (PD98059) and a PI3K inhibitor (LY294002) on the neuroprotective effect of meloxicam. SH-SY5Y cells were incubated at indicated concentrations of PD98059 (A, C) or LY294002 (B, D) with or without $10 \mu \mathrm{M}$ meloxicam for $24 \mathrm{~h}$ in the presence (solid column) or absence (open column) of $5 \mathrm{mM} \mathrm{MPP}{ }^{+}$. Cell toxicity was assesed by either cell viablitiy (A, B) or LDH leakage (C, D). Each value represents mean \pm SEM of 4 independent experiments. Differences where $p<0.05\left(^{*}\right)$ and $<0.001(* *)$ were significant by the Tukey's test for one-factorial ANOVA.

Fig. 5 - Involvement of anti-apoptotic intracellular signaling pathway in the neuroprotective effect of meloxicam. SH-SY5Y cells were incubated with the test-agents: $\mathrm{MPP}^{+}(5 \mathrm{mM})$, meloxicam $(30 \mu \mathrm{M})$ and LY294002 $(10 \mu \mathrm{M})$. $\quad$ (A) The smear DNA fragmentation pattern on the agarose gel after having cells incubated with $\mathrm{MPP}^{+}$for $24 \mathrm{~h}$ was blocked by the co-incubation with meloxicam. This protective effect was cancelled by the addion of LY294002. (B) Cleavage of caspase-3 was analyzed after having cells incubated with $\mathrm{MPP}^{+}$for $18 \mathrm{~h}$ by Western blot analysis. Illustrated lanes represent: molecular markers (M); vehicle (lane 1); $\mathrm{MPP}^{+}$per se (lane 2); $\mathrm{MPP}^{+}$with meloxicam (lane 3); $\mathrm{MPP}^{+}$with meloxicam and LY294002 (Lane 4). These representative patterns were from 3 - 4 independent experiments.

Fig. 6 - Effect of meloxicam on phosphorylation of Akt. The levels of Akt phosphorylation (A, B) and total Akt (C, D) were determined after 4-h (A, C) and 18-h (B, D) incubation with $\mathrm{MPP}^{+}(5 \mathrm{mM})$ and meloxicam $(30 \mu \mathrm{M})$ by Western blotting. Each value represents the mean \pm SEM of 3 - 4 independent experiments, with a representative 
image on western blotting of phospholylated Akt, Akt or $\beta$-actin. Differences where $p<$ $0.05(*)$ and $<0.001(* *)$ were significant were verified by the one-way factorial ANOVA followed by the Tukey's test.

Fig. 7 - Effects of meloxicam on the phosphorylation of ERK, JNK and p38 in $\mathrm{MPP}^{+}$-treated cells. Cells were treated with or without meloxicam $(30 \mu \mathrm{M})$ in the presence of $\mathrm{MPP}^{+}(5 \mathrm{mM})$ for $4 \mathrm{~h}$. Then, phospholyrated and total forms of ERK (A, B), JNK (C, D) and p38 (E, F) were detected by Western blotting. Each value represents mean \pm SEM of $3-4$ independent experiments. No statistical significance between any 2 groups was observed by the one-way factorial ANOVA.

Fig. 8 - The possible site of meloxicam action in preventing $\mathrm{MPP}^{+}$-induced cell death. $\mathrm{MPP}^{+}$inhibits Akt phosphorylation, and then activates Bad and/or, possibly, JNK to induce cell death. However, meloxicam prevents the reduction of Akt phosphorylation induced by $\mathrm{MPP}^{+}$and normalized PI3K/Akt signaling to suppress Bad and/or JNK, thus resulting in preventing and delaying cell survival.

Supp Fig. 1 - Effects of meloxicam on the phosphorylation of Akt in rotenone-treated cells. Cells were treated with or without meloxicam $(30 \mu \mathrm{M})$ in the presence of rotenone $(30 \mu \mathrm{M})$ for $18 \mathrm{~h}$. Phosphorylated (A) and total forms (B) of Akt were detected by Western blotting. Each value represents mean \pm SEM of three independent experiments. No statistical significance was verified by the one-way factorial ANOVA. 
Fig. 1

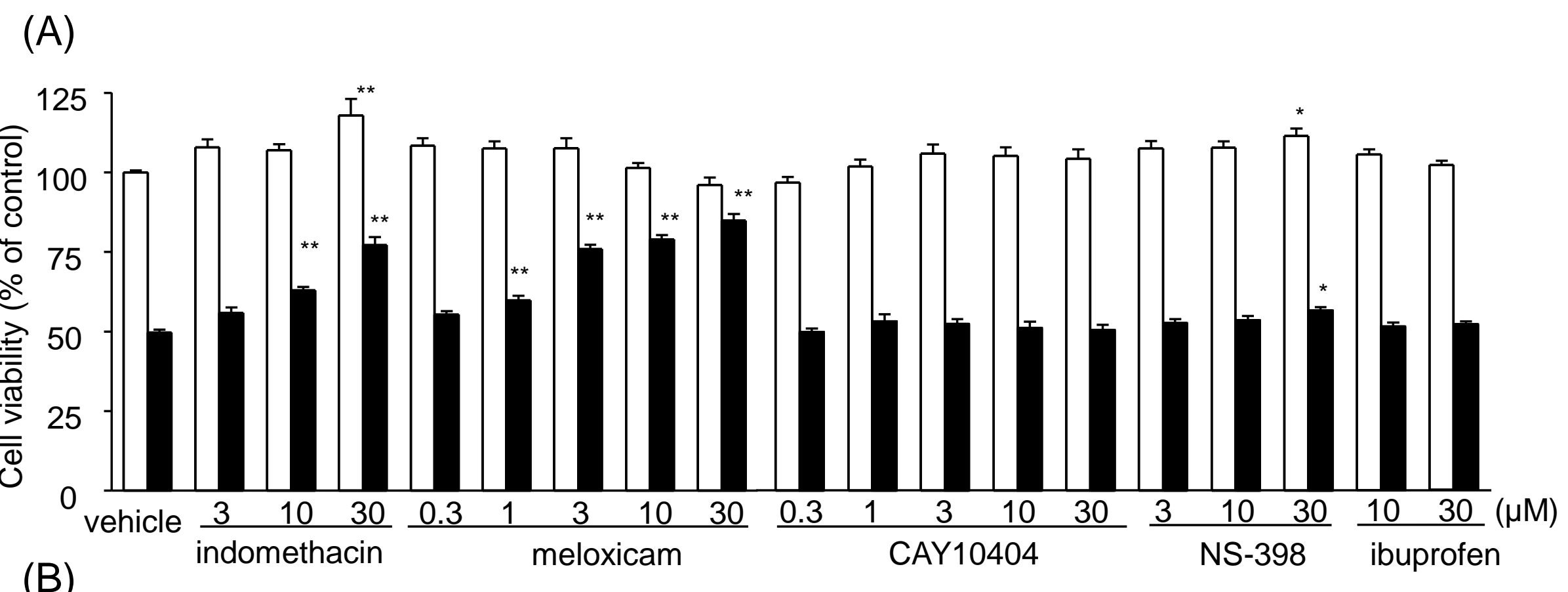

(B)

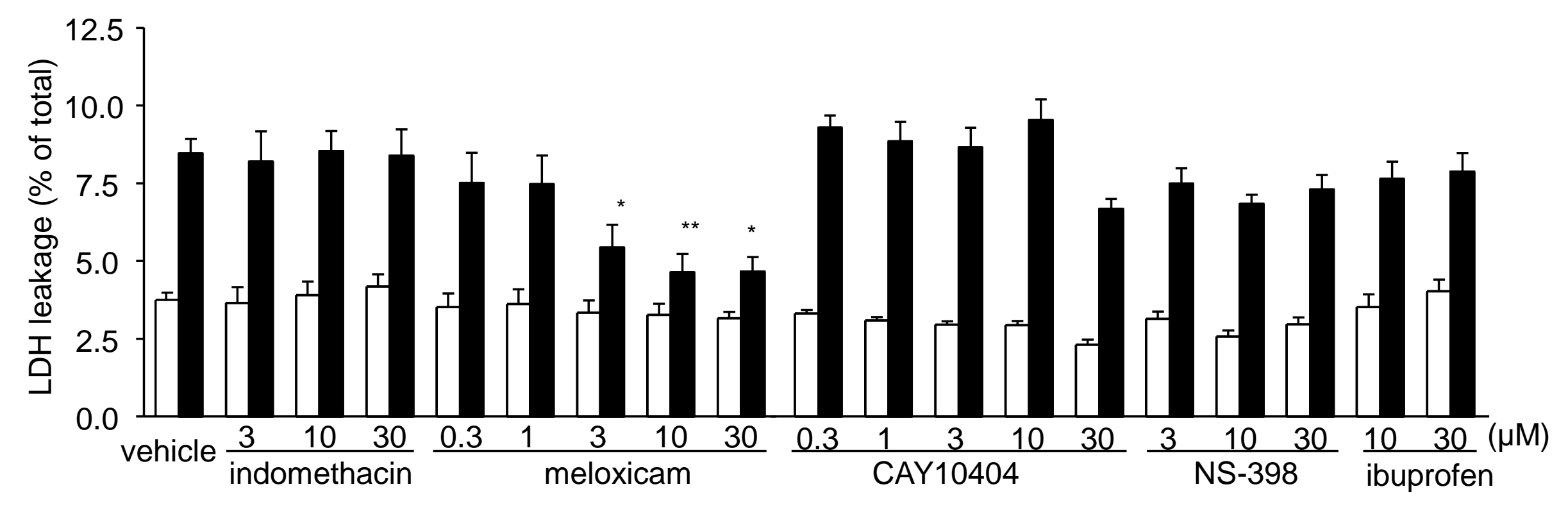


Fig. 2

(A)

(B)

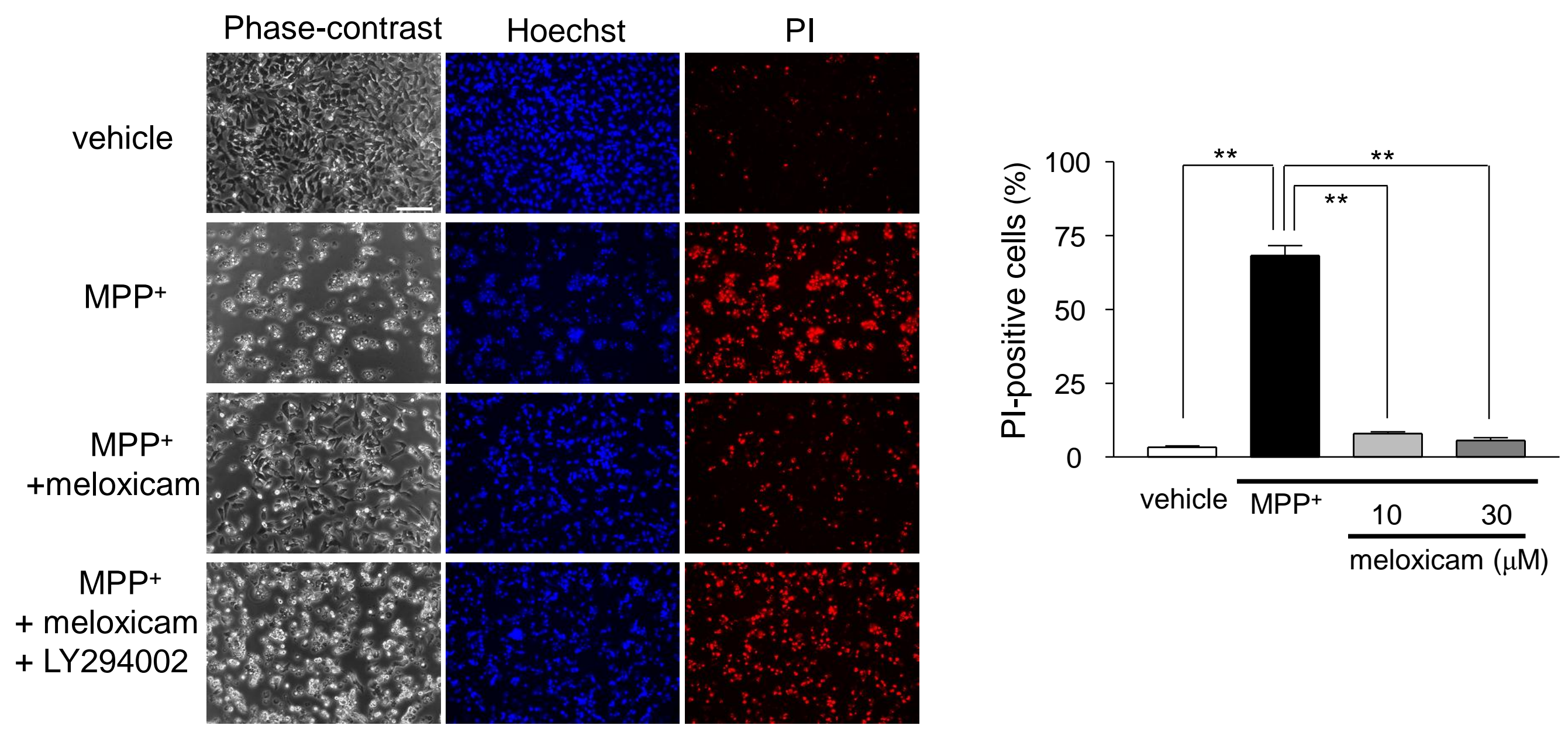


Fig.3

(A)

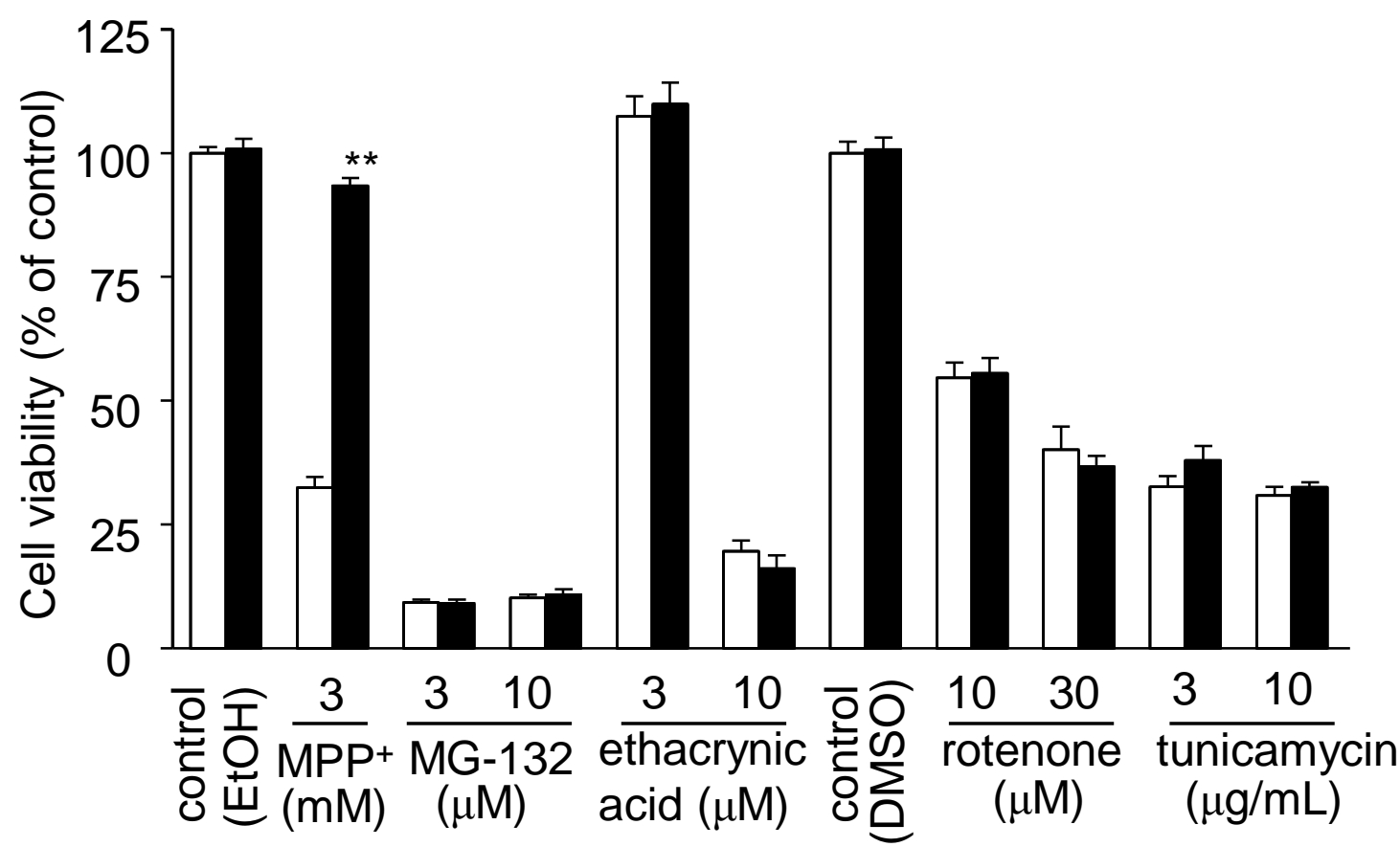

(B)

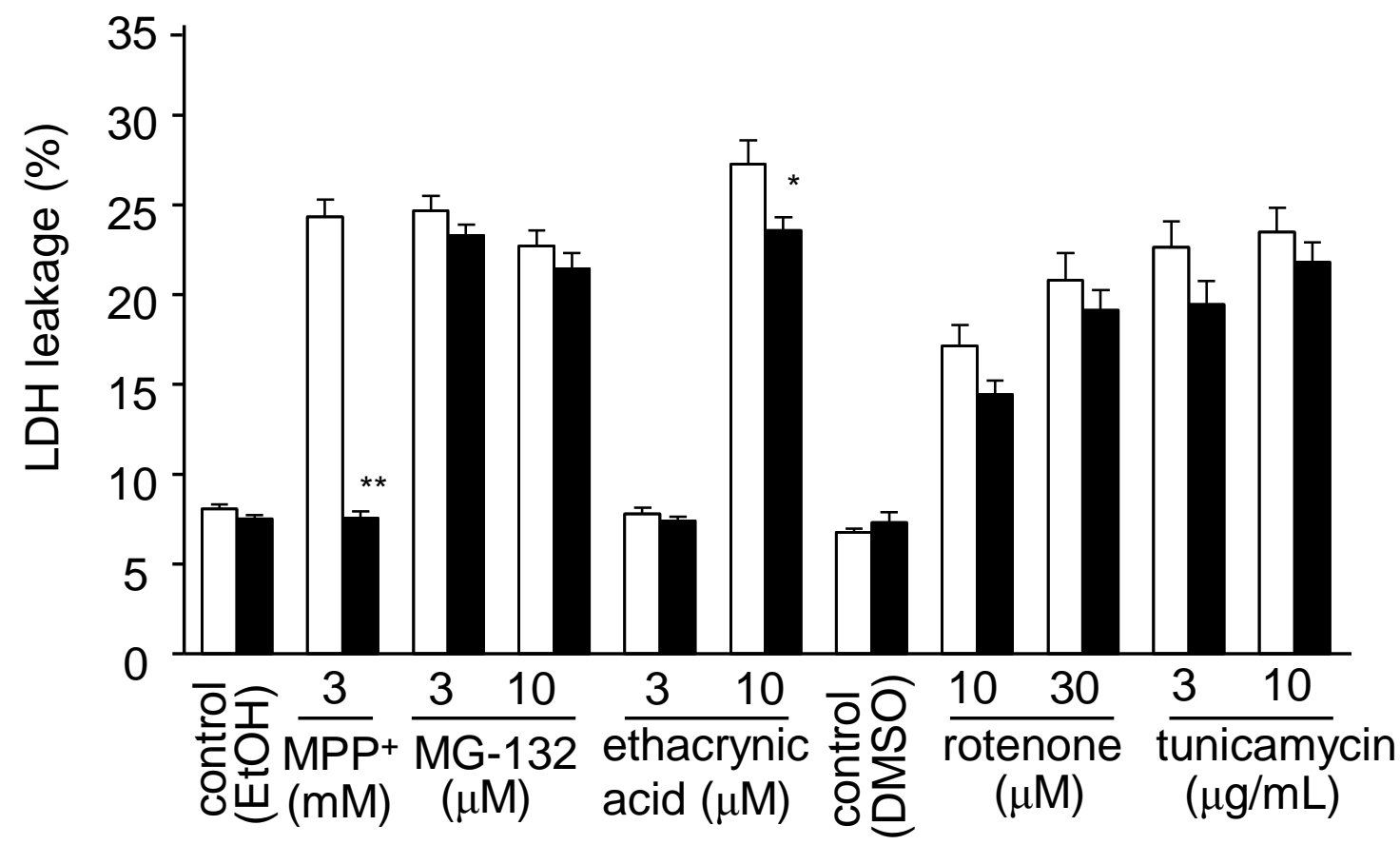


(A)

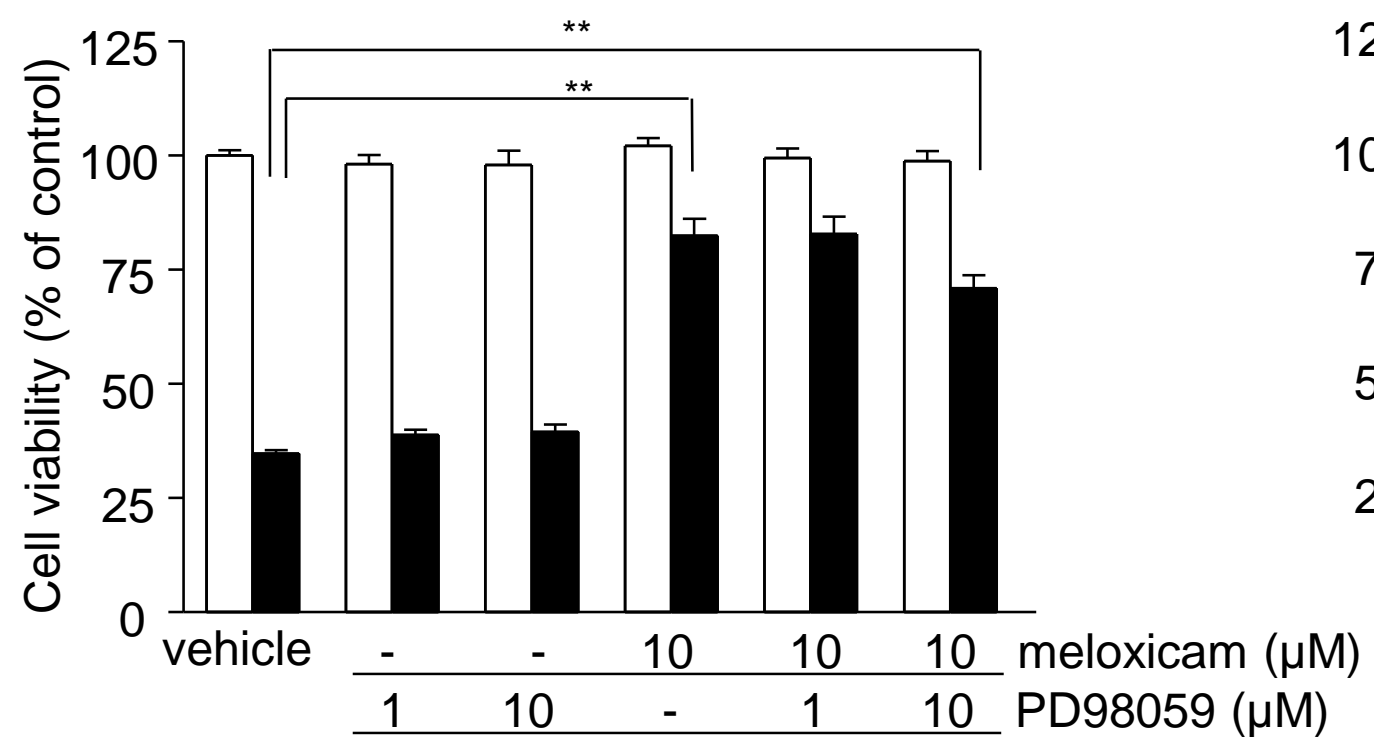

(B)

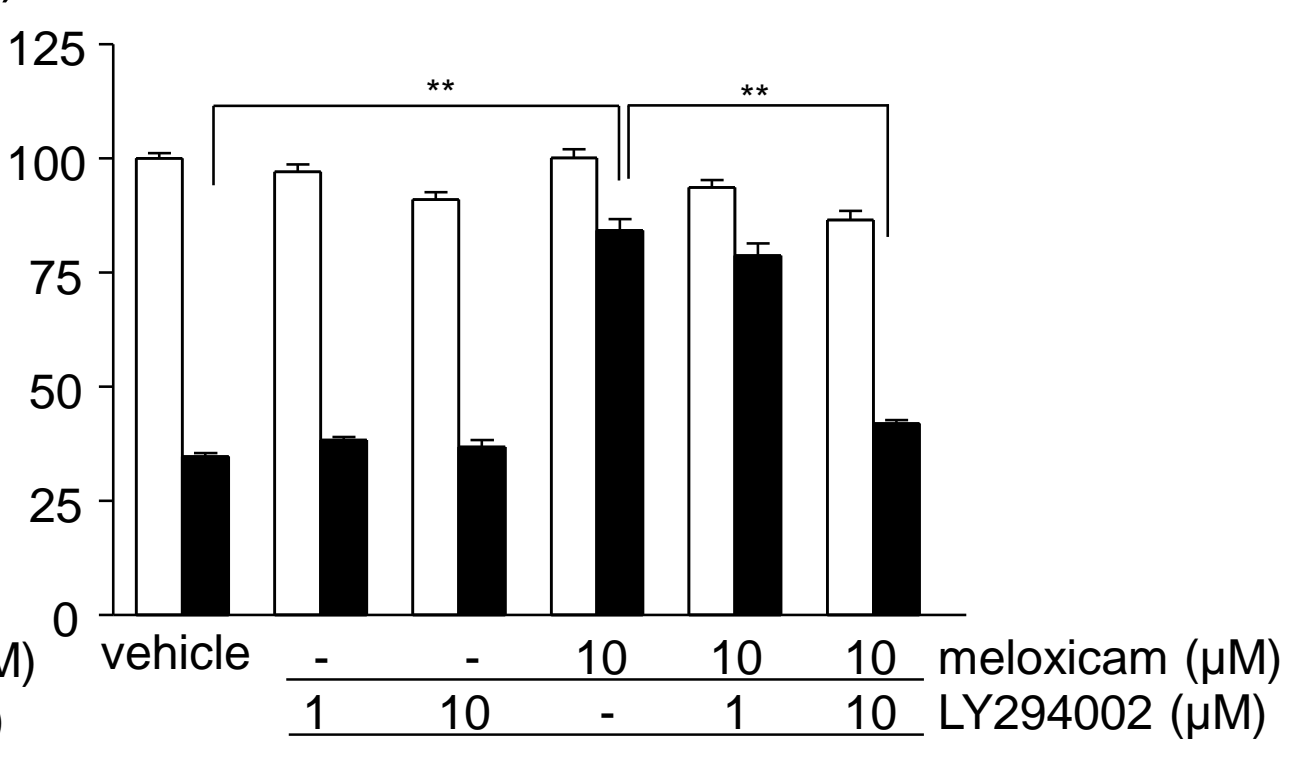

(C)

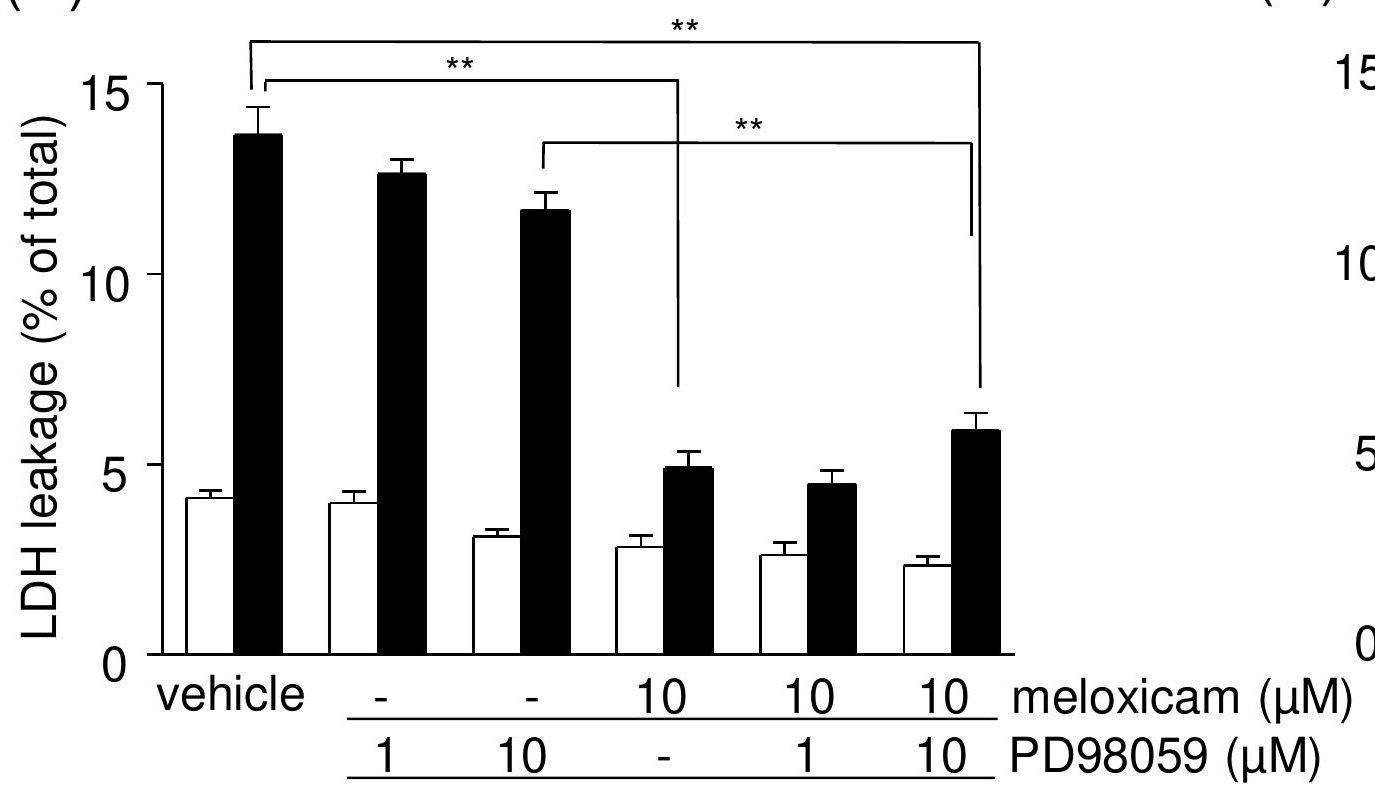

(D)

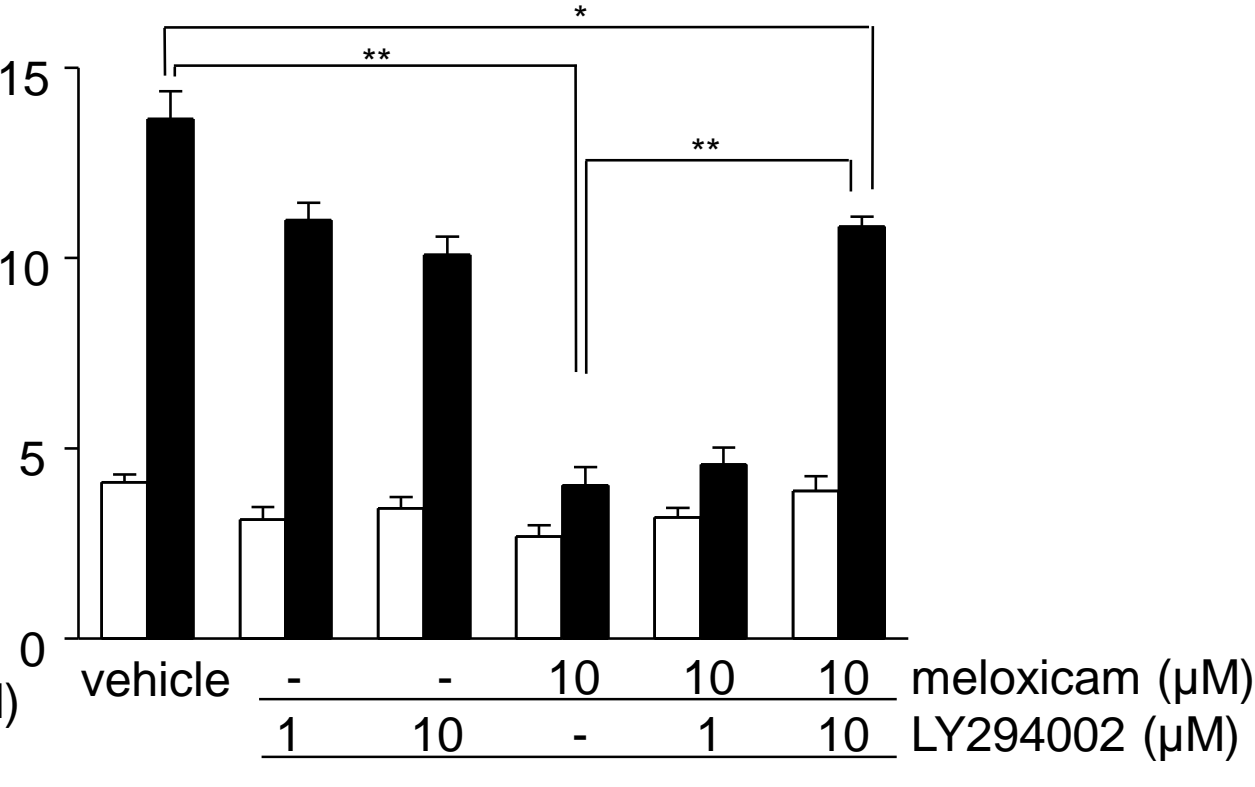


Fig. 5

(A)

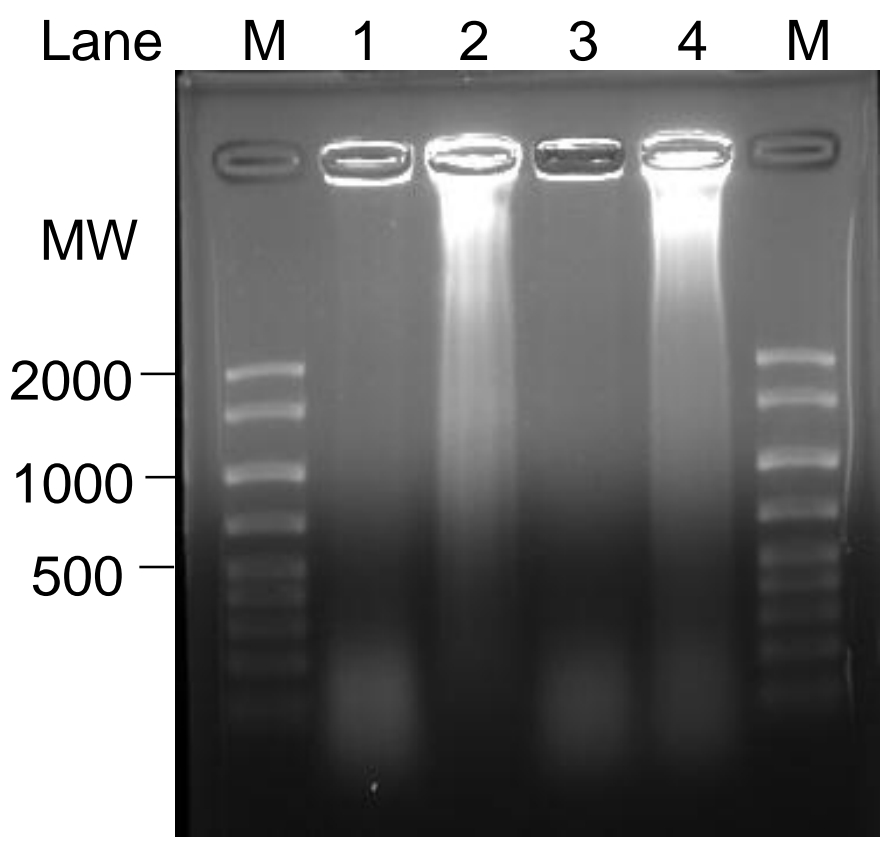

(B)

$$
\begin{aligned}
& \text { caspase-3 } \\
& \text { cleaved } \\
& \text { caspase-3 } \\
& \beta \text {-actin }
\end{aligned}
$$


Fig. 6

A

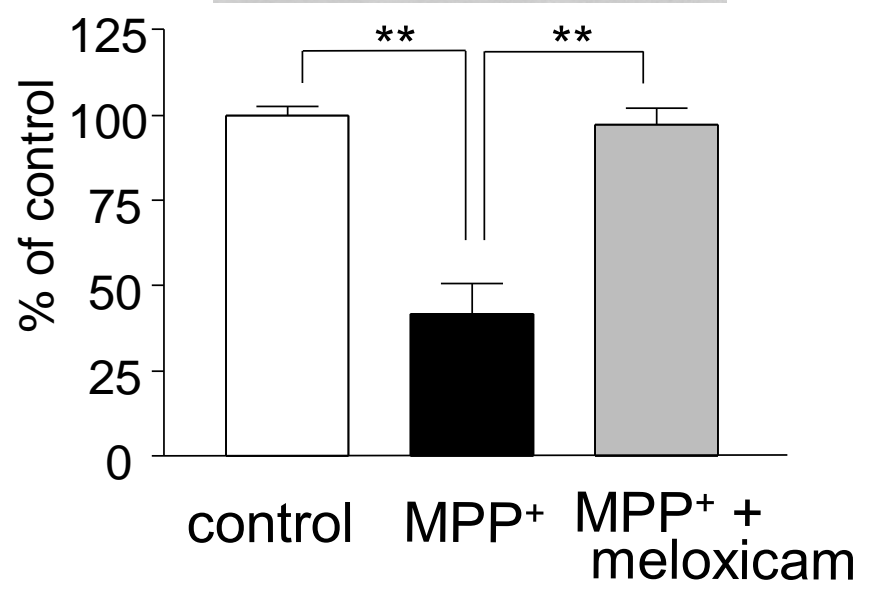

C

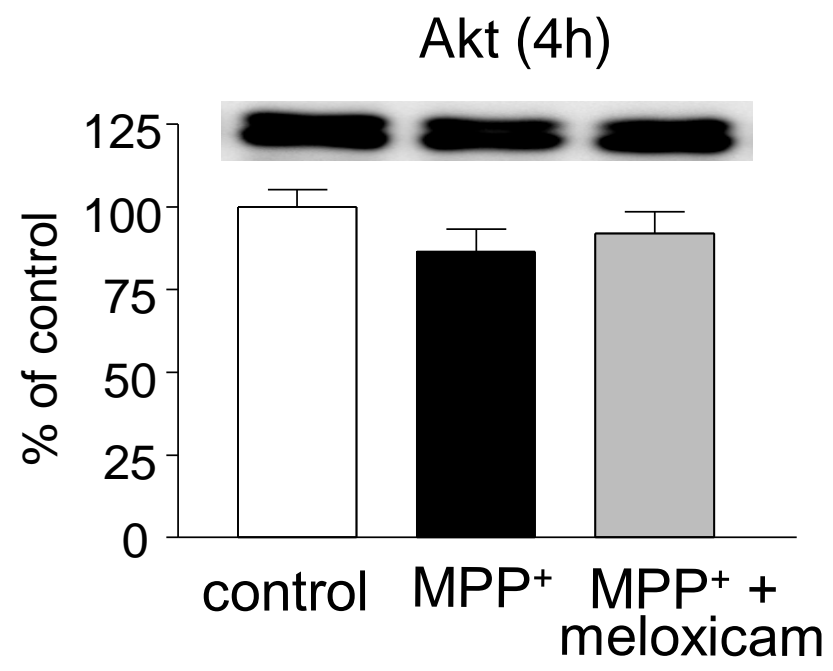

B pAkt (18h)

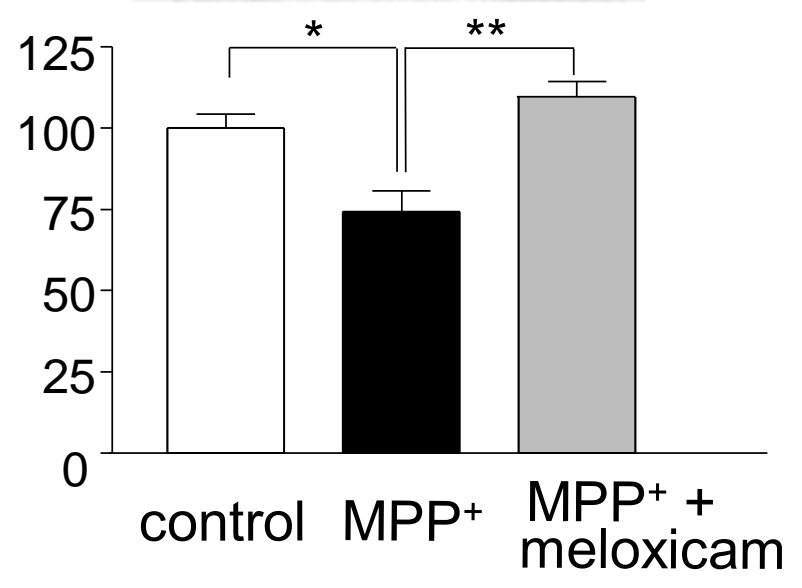

D

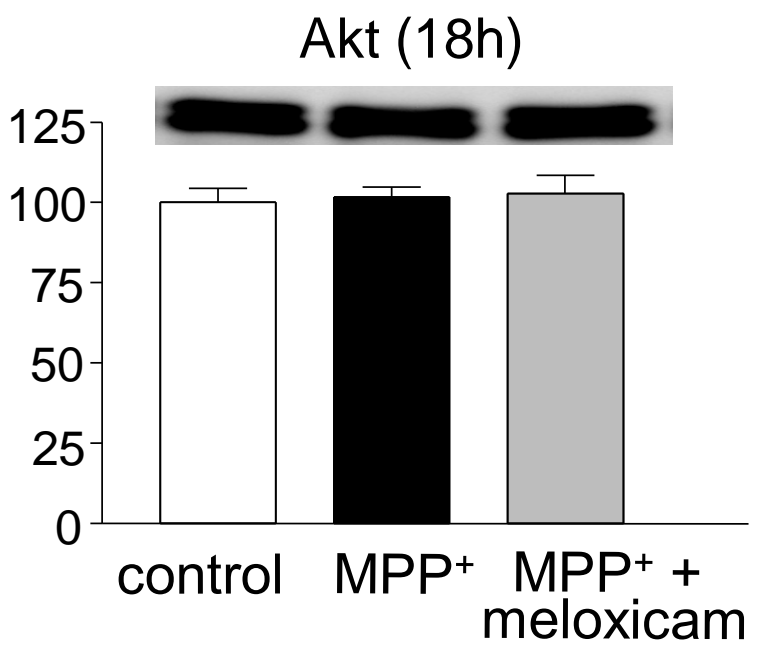

$\beta$-actin (4h) $\beta$-actin (18h) 
Fig. 8

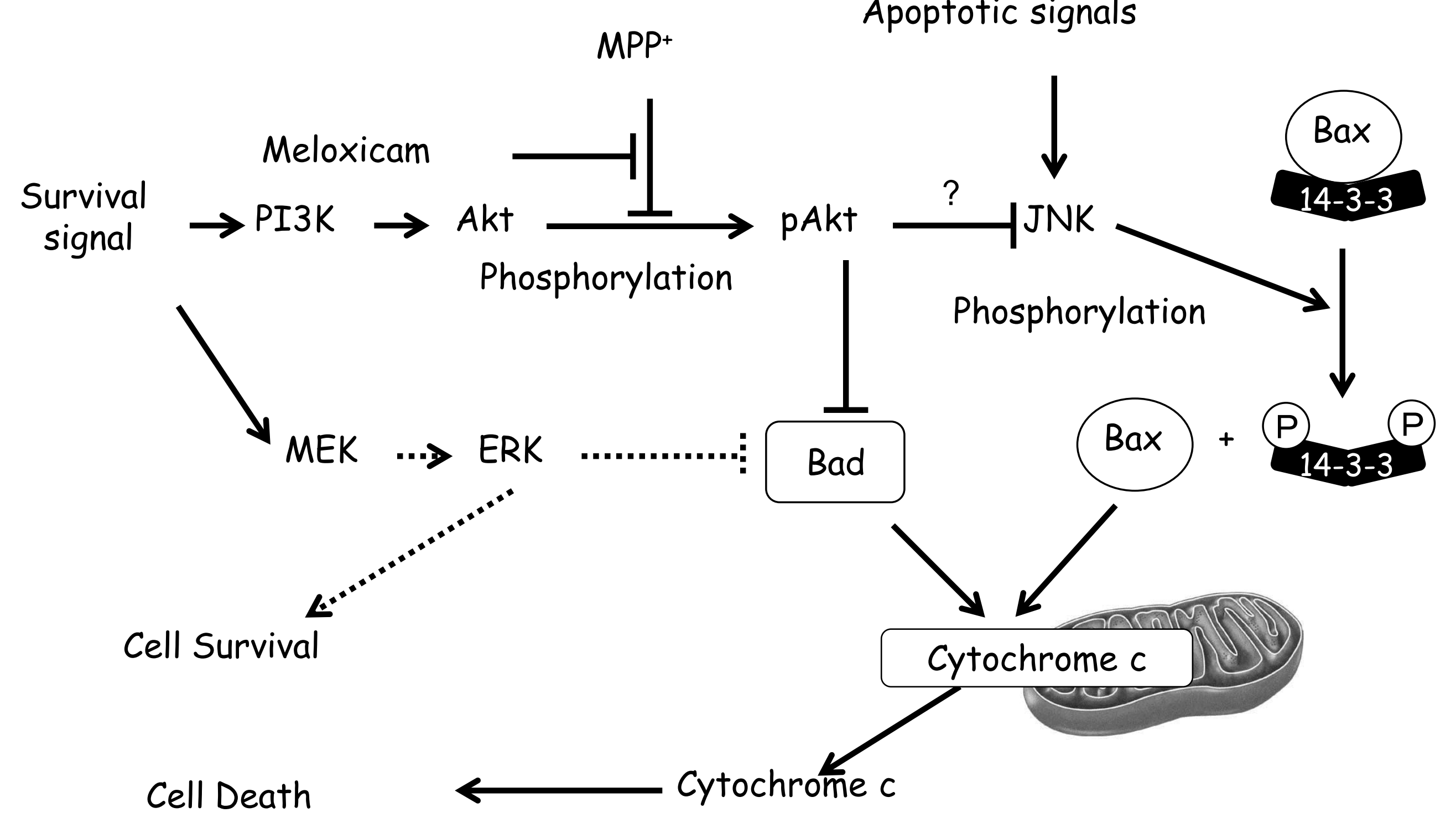


(A) pAkt

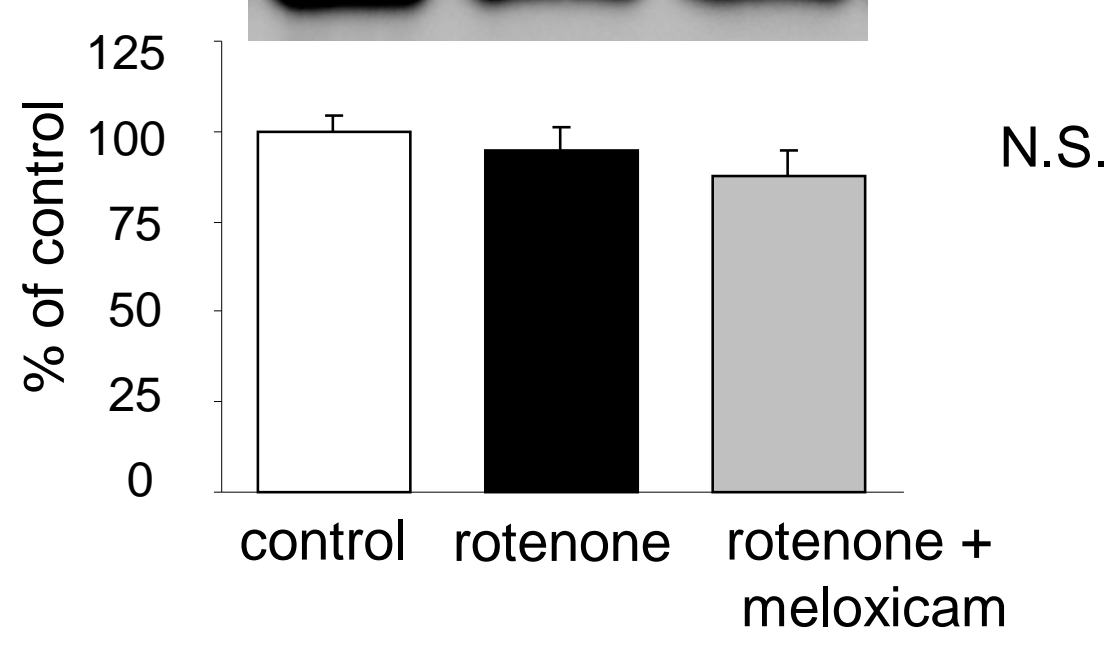

(B) Akt

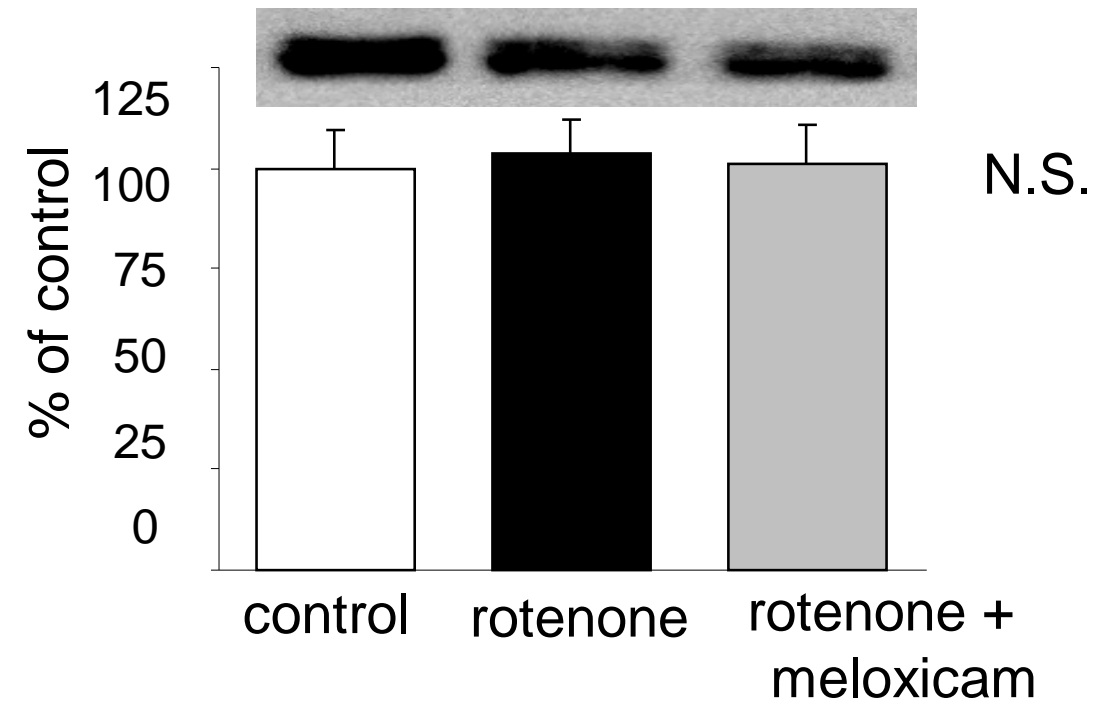

$\beta$-actin 